\title{
Effects of the Organophosphorous Methyl Parathion on the Branchial Epithelium of a Freshwater Fish Metynnis roosevelti
}

\author{
Marcelo Rubens Machado* and Edith Fanta \\ Universidade Norte do Paraná; Avenida Paris, 675; 86041-140; Londrina - PR - Brazil. Universidade Federal do \\ Paraná; Departamento de Biologia Celular; C. P. 19031; 81531-970; Curitiba-PR-Brazil
}

\begin{abstract}
Gills are vital structures for fish, since they are the main site for gaseous exchange as well as partially responsible for osmorregulation, acid-basic balance, excretion of nitrogenous compounds and taste. Chemicals in the water may alter the morphology of branchial cells of fish that are, therefore, a useful model for environmental impact and ecotoxicology studies. In order to investigate the effects of an organophosphorous compound, methyl parathion, on the gills of the fish, samples of Metynnis roosevelti were exposed to lethal (7ppm) and sublethal (1ppm) doses of Mentox 600 CE. Through light and scanning electron microscopy, shrinking of the branchial epithelium, followed by detachment and hyperplasia were observed. Externally, the branchial filaments presented the gradual disappearance of microridges. Even in sublethal doses, the organophosphorous reduced the health and fitness of these fish, as consequence of secondary effects derived from changes in the branchial epithelium, impairing oxygenation and ionic balance of the organism.
\end{abstract}

Key words: Gill, fish, methyl parathion, toxicity, morphology

\section{INTRODUCTION}

The effects of pollutants on aquatic animals can be assessed by population studies, in particular through the evaluation of the survival rates and reproductive success. However, as in aquatic animals gills are directly exposed to the environment, they may also be used as indicators of water quality (Rankin et al., 1982).

Fish gills play vital roles, since they are the main site of gaseous exchanges (Hughes, 1966; Hughes, 1982). Furthermore, they are involved in osmorregulation (Gonzales and McDonald, 1992; Flik and Verbost, 1993; Romão et al., 2001; Verbost et al., 1994), acid-base balance (Epstein et al., 1980; Evans et al., 1982; Lin and Randall, 1991; McDonald et al., 1991; Goss et al., 1992), excretion of nitrogenous compounds (Goldstein, 1982; Evans and Cameron, 1986; Sayer and Davenport, 1987), and taste (Hughes, 1982; Rios and Fanta, 1998).

Organic Pesticides (Davis and Wedemeyer, 1971; Rao and Rao, 1981; Mallatt, 1985; Evans, 1987; Laurent and Perry, 1991; Nowak, 1992; Wendelaar Bonga and Lock, 1992), detergents (Schimid and Mann, 1961; Abel, 1976; Bolis and Rankin, 1980), acids (Daye and Garside, 1980; McDonald, 1983; Kawall, 1993), salts (Hossler, 1980; Luvizotto, 1994; Fanta et al, 1995), industrial waste (Mitz and Giesy, 1985; Stoker

\footnotetext{
* Author for correspondence
} 
et al, 1985; Lindesjöö and Thulin, 1994), ammonia (Smart, 1976; Arillo et al., 1979; Soderberg et al., 1984) and heavy metals (Skidmore, 1970; Matthiessen and Brafield, 1973; Lock and van Overbeeke, 1981; Oronsaye and Brafield, 1984; Oliveira Ribeiro et al, 1994), can change the branchial epithelium and alter the activity of ATPase-Na-K, in that way, altering the normal flow of ions.

Therefore, fish gills can be used as model for studies on environmental impact (McKim and Erickson, 1991). Laurent and Perry (1991) consider the morphologic changes in gills, as a consequence of environmental changes, as adaptive attempts in conserving some physiological functions.

Rao and Rao (1981) investigated the effects of the organophosphorous (OP) compound methyl parathion on the synthesis of lipid derivatives in different tissues of fish (muscle, gill, liver, and brain). Quantitative analyses showed both, the decrease of all lipids and phospholipids, and the increase of free fatty acids in fish exposed to 0.09 ppm for 48 hours (sublethal concentrations). Based on these results, the authors suggested that there was a larger demand of energy for the fish in this condition.

Methyl parathion is one of several OP pesticides developed to substitute organochlorides. OPs are less persistent in the atmosphere, being easily linked to organic matter, being adsorbed to sediments and particled material in suspension (EPA, 1986).

The toxicity of methyl parathion is the result of a metabolic conversion processed in the endoplasmic reticulum of the hepatocytes, where the group $\mathrm{P}=\mathrm{S}$ is transformed into $\mathrm{P}=\mathrm{O}$. This process affects directly the morphology of the hepatocytes (Rodrigues and Fanta, 1998). The resultant compound, paraoxon, is responsible for the inhibition of several enzymatic systems (colinesterase, carboxilase, acetylcolinesterase and mitochondrial oxidative phosphorilase). The inhibition of $\mathrm{AChE}$ is the most critical toxic effect because it results in the accumulation of the neurotransmitter acetylcholine in the synapsis, interrupting the neural transmission. Although substantial reductions in the activity of AChE of the brain of fish have not been fatal, the effect of this condition on activities as feeding, reproduction and relationships prey-predator is not known (EPA, 1986; Silva et al., 1993).
OP compounds are more biodegradable than the organochloride, and therefore, often used to combat insects. According to the Bayer technical information manual, methyl parathion is the single product recommended officially for the control of the insect "broca" (Eutinobothrus brasiliensis) in the State of Paraná, therefore, being extensively used in agriculture. It is active against the main plagues that attack cotton, garlic, rice, potato, coffee, onion, citrus, bean, tobacco, corn, soybean, tomato and wheat cultures. Due to of rains or soil drainage, it often contaminates water bodies, affecting non target organisms such as fish. This is the reason why this product was chosen for this study.

Acute toxicity tests in fish are required by the Brazilian legislation that regulates and classifies the pesticides used in Brazil. Despite Brachydanio rerio being a species thoroughly used in these bioassays, due to its easy maintenance in laboratory conditions, it is not a native species of the Brazilian ichthyofauna. However, Metynnis roosevelti is a native species from Brazilian rivers, where OPs are often used, and therefore a possible victim of their effects in the natural environment. Thus, our purpose was to use the morphology of the gills of $M$. roosevelti as indicators of the effects of lethal and sublethal effects of the organophosphorous compound methyl parathion.

\section{MATERIALS AND METHODS}

\section{Biological material}

Metynnis roosevelti Eigenmann, 1915 (Serrasalmidae) was obtained from fish farms of the State of São Paulo. Fishes of total length 4.0 $5.0 \mathrm{~cm}$, mean weight of $3.0 \mathrm{~g}$, were maintained in 30 litres aquaria, protected by green shields to avoid external stimuli of the fish (Fanta, 1995) and to improve their adaptation. The fishes were acclimated for two weeks to laboratory conditions (temperature $25^{\circ} \mathrm{C} ; \mathrm{pH} \mathrm{7.0;} \mathrm{photoperiod} 8$ hours light/16 hours dark). They were fed once a day, one hour after the start of the light period with commercial pellets.

\section{Tested substance}

Mentox $600 \mathrm{CE}^{\circledR}$ is an insecticide that contains $600 \mathrm{~g} / \mathrm{l}$ of the active principle the organophosphorous methyl parathion. It is a colorless liquid, and has a strong scent. The 
product used in the experiments was supplied by the Mentox Industry.

\section{Toxicity tests}

Experiments were carried out in 30 liters aquaria, kept in the same conditions as during acclimation. Three tests were carried out: (i) control - 10 fishes were maintained in water without pollutant; (ii) and (iii) experimental - 10 fishes were kept in each of the aquaria contaminated with OP. Environmental conditions were the same in all three aquaria, with the exception of the contaminant.

Metynnis roosevelti was contaminated with $7 \mu 1$ of $\mathrm{OP} /$ litre and $1 \mu \mathrm{l}$ of $\mathrm{OP} /$ litre. These concentrations were lower than the $\mathrm{LC}_{50}$ for Brachydanio rerio $(8.5 \mu \mathrm{l} \mathrm{OP} /$ litre) in acute tests (96 hours). Seven ppm concentration caused the smallest number of dead individuals (1 fish in 96 hours of exposition). On the other hand, the concentration of $1 \mathrm{ppm}$ was chosen because it was the smallest concentration used in toxicity tests with $B$. rerio. The results of these tests obtained by laboratories validated by IBAMA (Brazilian Environmental Institute), are used for the establishment the toxicity degree of the product.

\section{Behaviour}

A qualitative observation of some behavioural items was done with all fishes through on the experiment, mainly respiration, activity, balance, grouping, prefered region in the experimental aquaria. No numerical evaluation was done.

\section{Gills}

Gills of $M$. roosevelti were sampled for histology and for scanning electron microscopy. The $2^{\text {nd }}$ right branchial arch was dissected out at 1, 4 and $8 \mathrm{~h}$ after exposure to $7 \mathrm{ppm}$ OP. From fishes contaminated with $1 \mathrm{ppm}$, the second right branchial arch was collected at 1, 4, 8, 24, 48, 72, and $96 \mathrm{~h}$ after $\mathrm{T}_{0}$. At the same times, gills from control fish of both experiments were also extracted.

For histology, the gills were fixed in Bouin for 8h, routinely prepared, and the sections stained with hematoxylin and eosin (HE) (Culling et al., 1985). For scanning electron microscopy, $2^{\text {nd }}$ left branchial arch was fixed in glutaraldehyde $2.5 \%$, diluted in $0.2 \mathrm{M}$ Cacodilate buffer $\mathrm{pH} 7.4$ at $4{ }^{\circ} \mathrm{C}$, overnight. The samples were washed in $0.5 \mathrm{M}$ Cacodylate, $\mathrm{pH} 7.4$, contrasted in $4 \%$ osmium tetroxide diluted in $0.2 \mathrm{M}$ Cacodilate, $\mathrm{pH} 7.4$ for $1 \mathrm{~h}$ at $4{ }^{\circ} \mathrm{C}$. The critical point was obtained in a Balzers CPD 030, and the metalization was done with gold in a Balzers SCD 050. Preparations were observed in a Jeol JSM 5300 scanning electron microscope.

\section{RESULTS}

\section{Control gills morphology}

Gills of Metynnis roosevelti had 4 pairs of cartilagenous branchial arches. Gill filaments or primary lamellae, were lined by a stratified squamous epithelium. At the epithelial surface, the polygonal cells showed concentric microridges. The apical portion of chloride cells was rarely observed among the epithelial cells of the filament (Fig. 1). Respiratory or secondary lamellae were leaf like structures in an oblique display to the primary lamellae. They were lined by a smooth squamous epithelium, without microridges at the cell surfaces, and with a prominent nucleus (Figures 1 and 2). There was a clear transition from the branchial filament to the respiratory lamella (Fig. 1). Respiratory lamellae had a thin epithelium, sustained by pillar cells that surround blood spaces (Fig. 2).

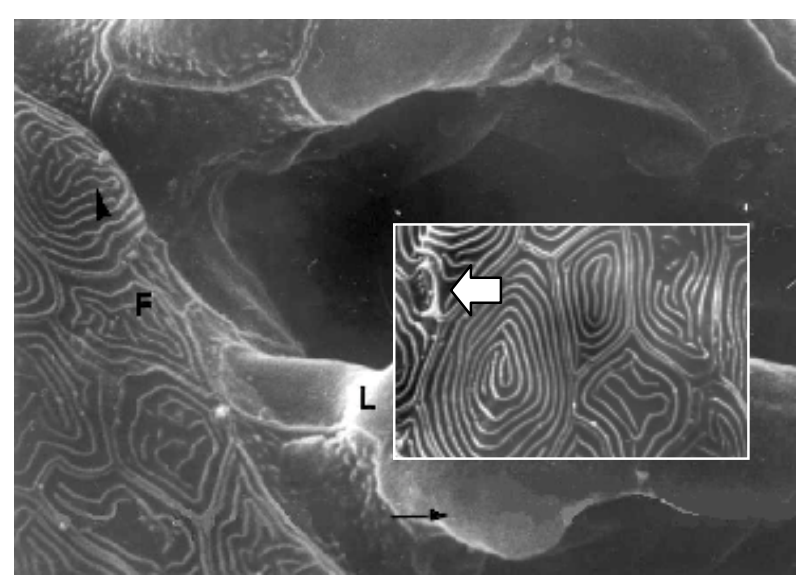

Figure 1 - SEM of the region of insertion of two respiratory lamellae (L) in the branchial filament $(\mathrm{F})$. Notice the absence of microridges at the respiratory epithelium and their presence at the primary lamella (arrow head). The arrow indicates a prominent nucleus (3500x). In the detail, the surface of epithelial cells in the filament, and a chloride cell apex (white arrow) (7000x). 


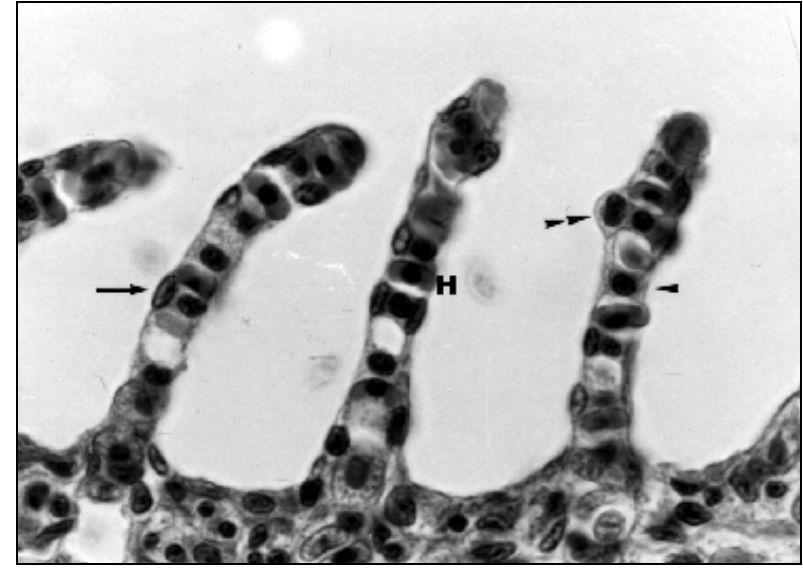

Figure 2 - Respiratory lamellae with squamous cells (arrow), pillar cells (arrow head), and erythrocites $(\mathrm{H})$. The double arrow indicates a prominent nucleus. (1000x).

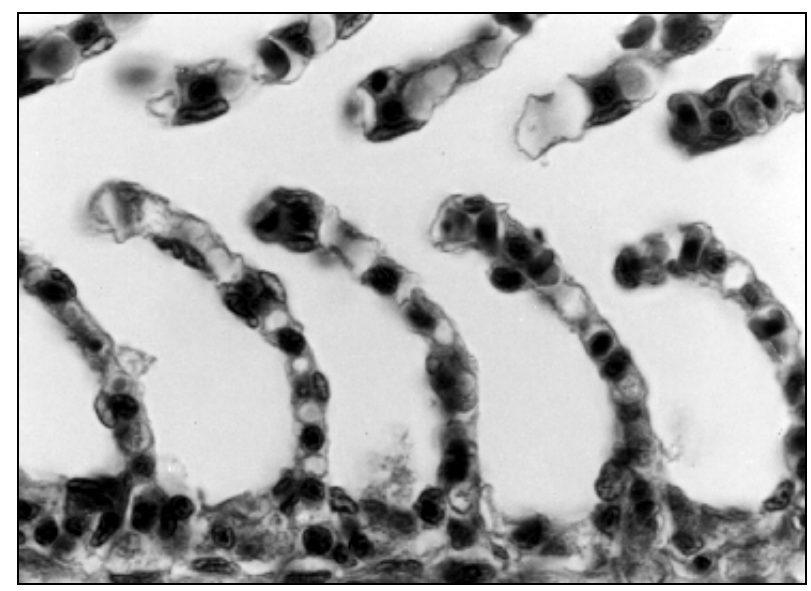

Figure 3 - Altered respiratory lamellae. Notice the corrugated epithelium and the disorganization of the lamellar structure (7ppm-1h) (1000x).

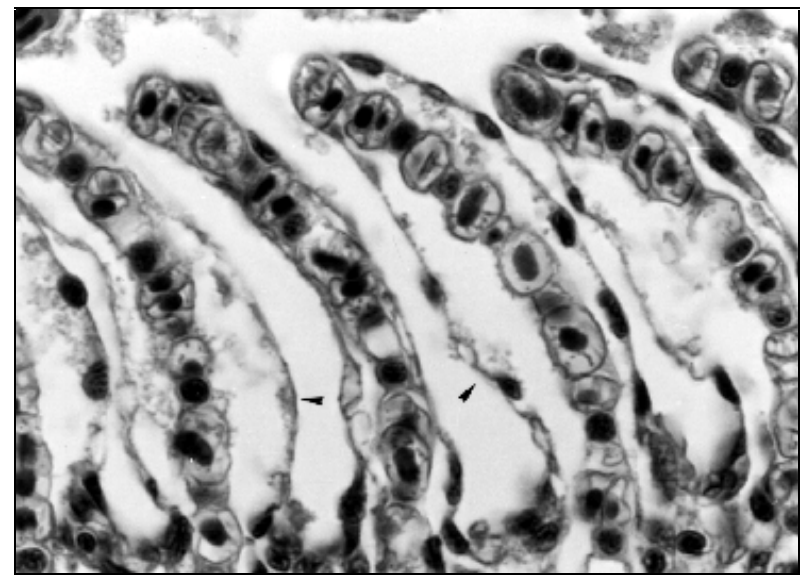

Figure 4 - Epithelial detachment (arrow head) in fish exposed to OP (7ppm-4h) (1000x).

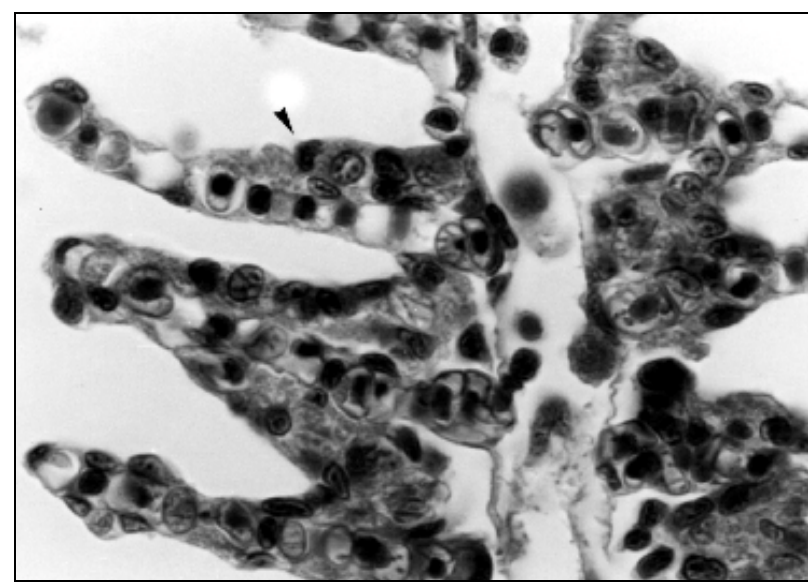

Figure 5 - Hyperplasia (arrow head). Notice the covering of the respiratory lamellae surface (7ppm-8h) (1000x).

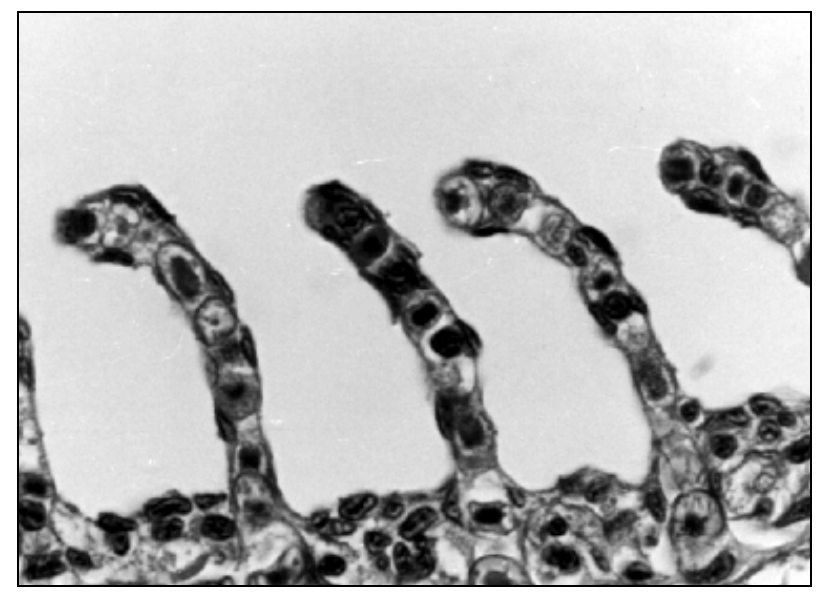

Figure 6 - Alterations in the cell morphology of fish exposed to $1 \mathrm{ppm}$ of $\mathrm{OP}$, for $1 \mathrm{~h}(1000 \mathrm{x})$.

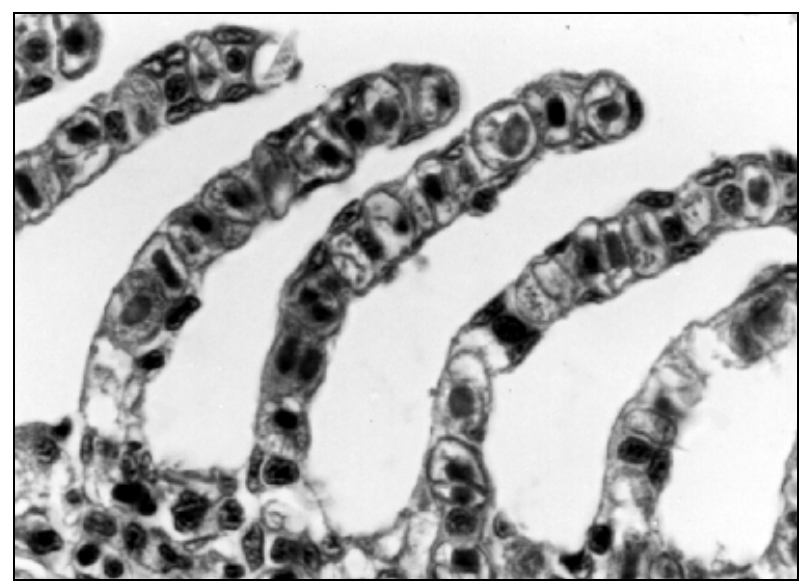

Figure 7 - Epithelium wrinkling of respiratory lamellae was observed after exposure to $1 \mathrm{ppm} \mathrm{OP}$, for $24 \mathrm{~h}$ (1000x). 


\section{Effects of the organophosphorous compound on the gills of Metynnis roosevelti}

The effect of methyl parathion on the branchial epithelium was quite drastic: structural changes of the gill lamellae organization, epithelial detachment, necrosis, hyperplasia, loss of the microridges, altered cellular morphology. These features were observed in both concentrations.

\section{Bioassay 7ppm}

Time of exposure - $1 \mathrm{~h}$. Respiratory lamellae and interlamellar epithelium disorganization was observed. In addition, epithelium wrinkling of the respiratory lamellae was noticed (Fig. 3).

Time of exposure - 4h. Epithelial detachment in the respiratory lamellae was observed (Fig. 4).

Time of exposure - $8 h$. Hyperplasia was quite frequent, and cellular proliferation ocurred mainly on the surface of the respiratory lamellae (Fig. 5), that tended to fuse.

\section{Bioassay 1ppm}

Even at the concentration of $1 \mathrm{ppm}$, methyl parathion caused changes in the branchial epithelium of $M$. roosevelti.

Time of exposure - 1h. All branchial tissues were altered. The interlamellar epithelium became irregular, the surface corregated, and the cells thin, with flat nucleus. The shape of pillar cells was altered, and consequently the size and shape of blood spaces. The shape of erytrocytes became irregular, crenated with disform nucleus (Fig. 6).

Time of exposure - 4h. Degeneration of lamellar and interlamellar cells was observed. The blood spaces collapsed and the erytrocytes were weakly stained by eosine.

Time of exposure $-8 h$. The respiratory lamellae were quite narrowed with a significant flattening of the squamous cells nucleus. The cytoplasm of erytrocytes was weakly stained by eosine.

Time of exposure - 24h. Epithelium wrinkling of respiratory lamellae, cellular degeneration and collapse of the blood spaces were common. Disorganization and decrease in the amount of microridges at the epithelial cells surface of the primary lamellae, as well as generalized wrinkling was observed (Figures 7 and 8).

Time of exposure - 48h. Intense tissue degeneration and disorganization occurred, with consequent loss of blood spaces. Wrinkled, irregular lamellae, with discontinuous aspect, contrasted with their aspect in the control branchial epithelium (Fig. 9).

Time of exposure $-72 h$. At this time, epithelium detachment of respiratory lamellae was observed. However, the most evident alteration was observed at the surface of the filament epithelium, where microridges were substituted by cell membrane folds (Figures 10 and 11).

Time of exposure $-96 h$. The effects of the OP were similar to those observed after $72 \mathrm{~h}$. The detachment of the lamellar epithelium was intensified. At the surface of the filament cells showed changes in the shape of the microridges that either became punctiform or disappeared in some areas, giving place to a fold that covered the whole extension of the cells (Figures 12 and 13). 


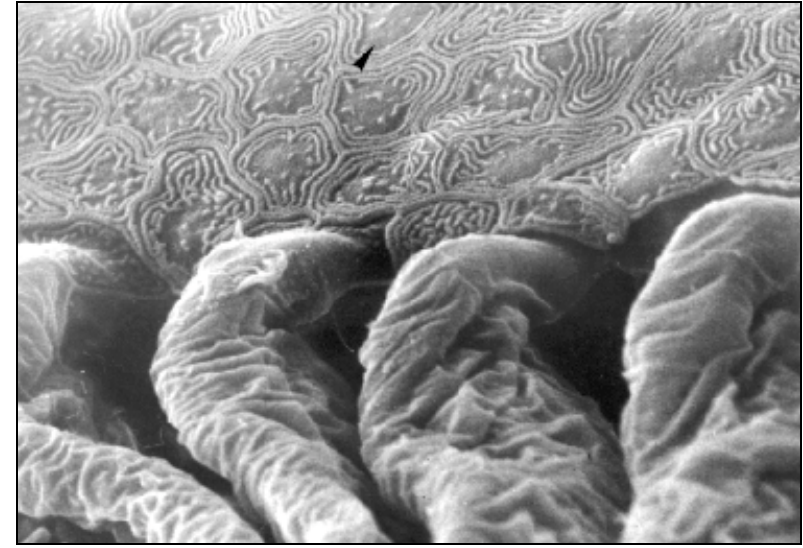

Figure 8 - Corrugation of respiratory lamellae epithelium. Notice the alterations in the microridges in the filament epithelium (arrow head). (1ppm-24h) (SEM 2000x).

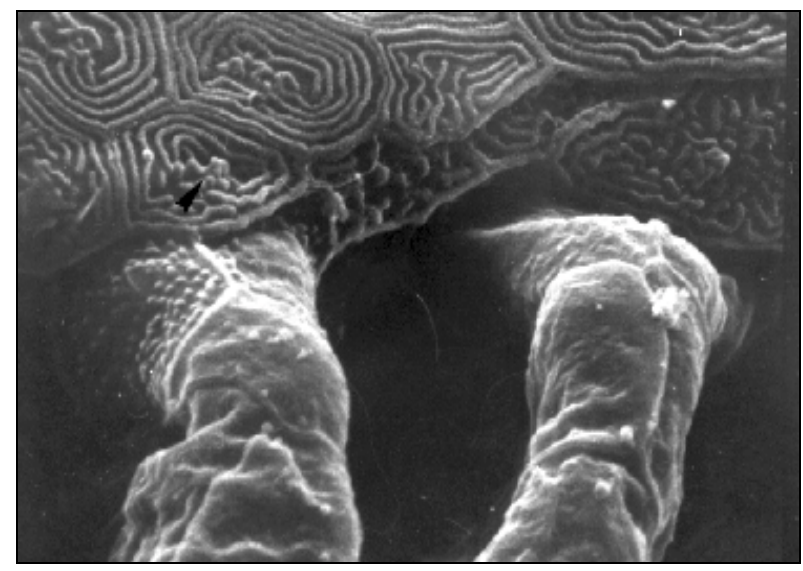

Figure 9 - Corrugation persists after $48 \mathrm{~h}$ in $1 \mathrm{ppm}$ OP. Notice the reappearance of microridges in the central part of epithelial cells of the filament (arrow head) (SEM 2000x).

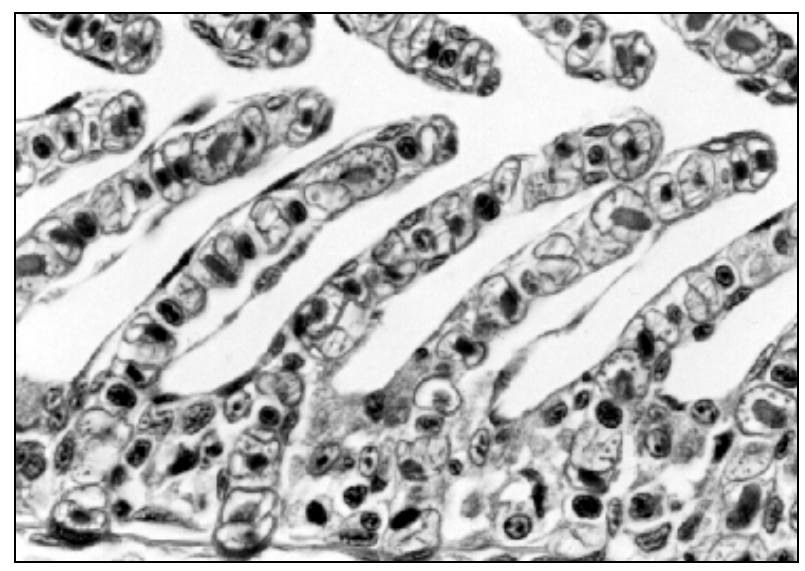

Figure 10 - Detachment of the epithelium in 1ppm OP, after $72 \mathrm{~h}(1000 \mathrm{x})$.

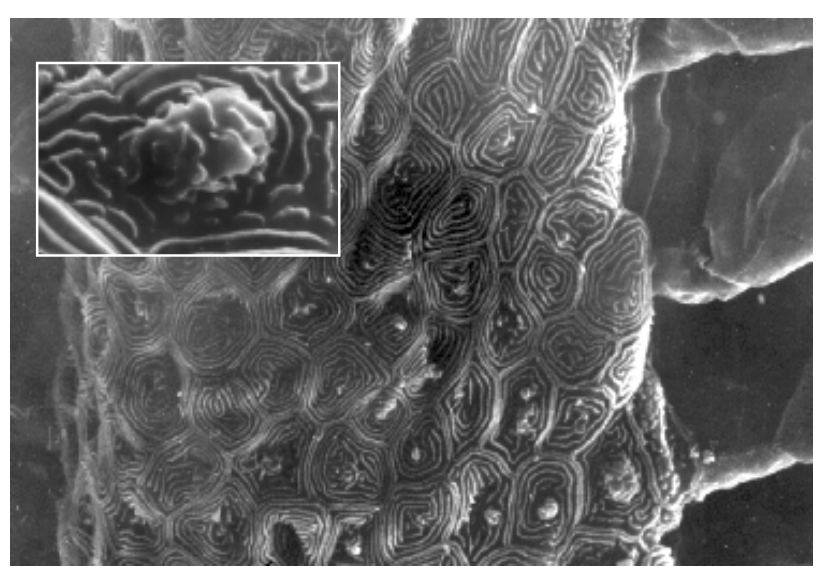

Figure 11 - Corrugation in the branchial filament (SEM 2000x). In the detail, folds of the cell membrane (1ppm-72h).

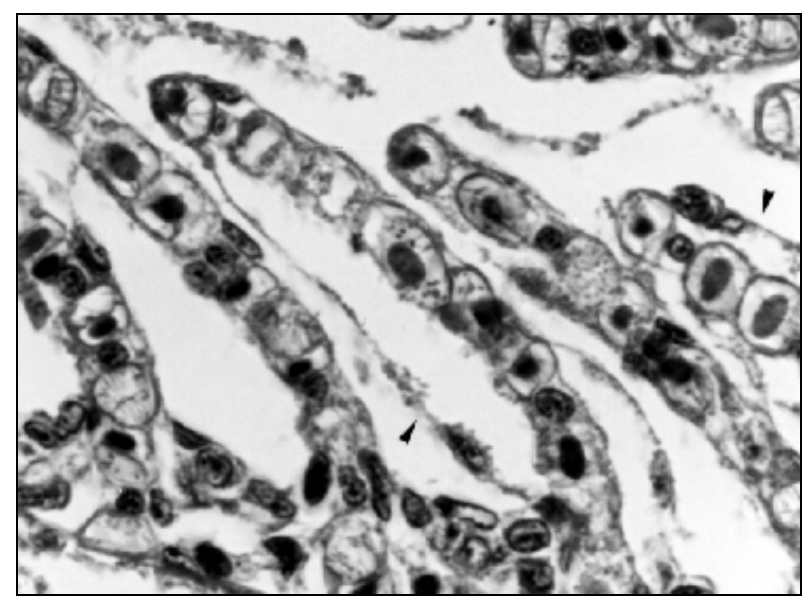

Figure 12 - Intensive detachment (arrow head) and cell degeneration (1ppm-96h) (1000x).

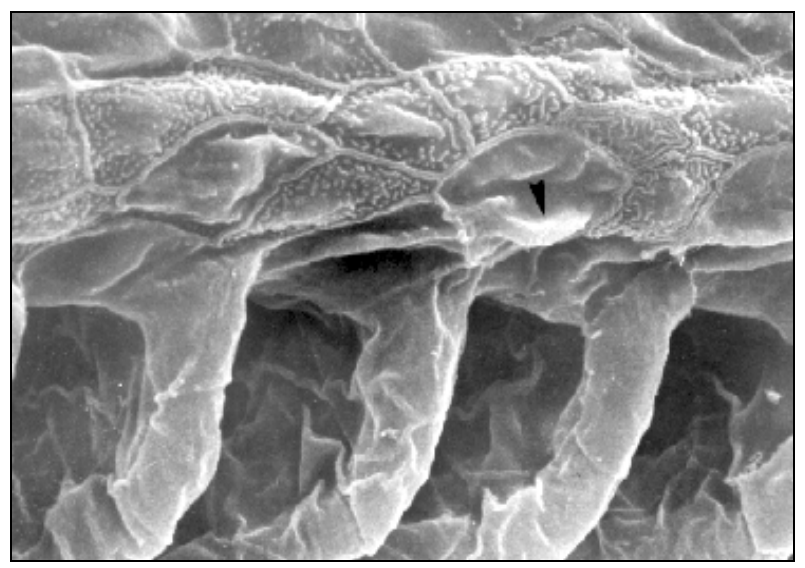

Figure 13 - Punctiform or absent microridges (arrow head) (1ppm-96h) (SEM 2000x). 


\section{Some behavioural symptoms of Metynnis roosevelti after contamination with $\mathrm{OP}$}

\section{Bioassay 7ppm}

The concentration of $7 \mathrm{ppm}$ of methyl parathion was lethal for $M$. roosevelti. All fish died after 8 hours of exposure. After 15 minutes in water with $\mathrm{OP}$, fish lost balance and intensified respiratory frequency. After 8 hours, the opercular and jaws movements connected to respiration stopped. Fishes kept the mouth constantly opened, and swam without rest, subsequently becoming lethargic and dying.

\section{Bioassay 1ppm}

The concentration of $1 \mathrm{ppm}$ of methyl parathion was sublethal to $M$. roosevelti, and all fishes survived for more than 96 hours of exposure. However, some behavioural changes were observed in the first 8 hours. All fishes remained close to the water surface. They did not form groups and the decrease of activity was evident. The fishes were most of the time in rest, while their respiratory movements were accelerated. There was recovery and noticeable return to the normal in the subsequent period until the end of the experiment.

\section{DISCUSSION}

Fish gills were chosen for this investigation because they were in direct contact with the aquatic environment and, therefore, could be good indicators of water quality.

Epithelial wrinkling and detachment, hyperplasia and alterations in the shape of microridges are common when the water quality changes. Mallatt (1985) analyzed 130 publications in which morphological changes of the respiratory epithelium due to the action of chemicals were registered. Lesions observed less than 10 times were not considered in his statistical analysis, and the wrinkling of the respiratory epithelium is among these lesions. However, in Metynnis roosevelti, this change appeared in the first hour after contamination, at both concentrations. This indicate probably an initial loss of the osmotic balance in the cells. The regression of the wrinkling afterwards could mean that the epithelium was still able to make some adjustments after an initial aggression.

Mueller et al. (1991), studying the effects of the aluminium on the branchial epithelium, proposed two phases to explain the morphological changes in the respiratory system of fishes. An initial phase that could last from some hours to days, which was characterized by the efflux of ions, the inhibition of the active reception of ions and interference in the gaseous exchanges. In a subsequent phase, there would be a return to the normal morpho-physiological characteristics.

Goss et al. (1992) propose that the squamous cells of the respiratory epithelium of freshwater fish took part in ionic regulation mechanisms. In fact, the ionic change $\mathrm{Na}^{+} / \mathrm{H}^{+}$, and the enzymes involved in this process were in the membrane of these cells. It was possible that a sublethal dose of methyl parathion changed the acid-base balance and the absorption of $\mathrm{Na}^{+}$in this freshwater fish, $M$. roosevelti, since the wrinkling reached the cell membrane.

It should also be taken into consideration that in the case of methyl parathion, one could observe two subsequent effects. The first effect was a result of the direct contact of the OP with the epithelial cells, including those of the respiratory epithelium, through which it entered the organism. Later, the organophosphorous compound, after having been metabolized in the liver, was distributed to the tissues through the blood flow in the form of methyl paraoxon.

Epithelial detachment in $M$. roosevelti was even observed in the sublethal concentration of OP. In Mallatt's review (1985), this was the most common branchial change that occurred in freshwater fishes rather than in seawater fish. This could be due to the fact that the first ones were hyperosmotic in relation to the environment, facilitating the influx of water through the epithelium lesion, increasing the volume in the oedema, and consequently the detachment. Abel (1976) repeated this process as being a decrease of the superficial area of the gills what was necessary to maintain the internal osmotic surrouding regarding the functional loss of the epithelial cells. Nowak (1992) found that the respiratory epithelium detachment resulted in the increase of the diffusion distance, affecting the gaseous exchanges. This phenomenon has also been described in another type of environmental contamination such as in acid waters (Kawall, 1993), heavy metals 
(Oliveira Ribeiro et al., 1994) and salinity (Luvizotto, 1994; Fanta et al., 1995).

In $M$. roosevelti, the hyperplasia was subsequent to the process of epithelial detachment, which suggested the former was a consequence of the latter. The hyperplasia was characterized by cellular proliferation in the interlamellar region of the repiratory lamellae, decreasing the surface area and making gaseous exchanges more difficult. Magor (1988) repeated that these cells stemed from the epithelium of the filament in the interlamellar space and could act as a barrier impeding the diffusion of harmful substances to the blood of the fish. Khan and Kiceniuk (1984), studying the histopathological effects of raw oil on fishes, found that hyperplasia, together with the mucus secretion, protected the gills against future damages caused by intoxicants. This alteration was extremely intense after contamination with heavy metals (Oliveira Ribeiro et al., 1994).

The branchial responses could be good to hinder the entrance of intoxicants in the blood flow, but they have the undesirable effect of decreasing the oxigenation of tissues, generating a barrier to gaseous exchanges (Mallatt, 1985). This breathing difficulty was confirmed by the behavioural response of $M$. roosevelti, because when exposed to the $7 \mathrm{ppm}$ lethal dose, the animals had strong breathing difficulties. It is possible, therefore, to trace a parallel among the hyperplasia and the behavioural effects of the intoxicated animals.

Nowak (1992) did not detect any significant difference in the diameter of the blood spaces surrounded by the pillar cells in fish exposed to the endosulfan organochloride. However, some studies report damages in the pillar cells caused by pollutants (Schimid and Mann, 1961; BettexGalland and Hughes, 1973; Abel, 1976). Such cellular damages are often associated to high doses in which the animals are close to death (Mallatt, 1985).

However, in $M$. roosevelti a different result was obtained after contamination with OP. At the first hour of exposition to the sublethal concentration, the whole structure of the respiratory lamella of $M$. roosevelti, including the shape of pillar cells, was altered. This collapse of the pillar cells progressive along the 96 hours of the experiment was followed by a loss of shape of the erytrocytes, what can indicate osmotic and ionic alterations.

The action of methyl parathion causes enzymatic inhibition, blocking the acetylcholinesterasis and other enzymes. It is not the methyl parathion that acts but the methyl paraoxon, that results from enzymatic oxidation mainly in the hepatocytes. The cholinesterase inactivation by methyl paraoxon is taken, chemically, as a phosphorilation, leaving the endogenous acetylcholine free (Barberá, 1976). Bettex-Galland and Hughes (1973), suggest that the contraction of pillar cells is facilitated by the acetylcholine in the blood.

Morphologic alterations of the pillar cells can have several secondary consequences. These cells control the blood pressure of the fish, and changes in the blood pressure and flow can affect the number of irrigated lamellae, the distribution of the blood within the lamellae, the permeability of the branchial epithelium and, as a consequence, the osmorregulatory and gaseous exchange mechanisms (Randall, 1982), causing several physiological disorders.

The deformation of erytrocytes was obvious, and has possibly reduced the capacity of oxygen transport, consequently causing a certain level of hypoxia. Consequently, the fish tries to compensate the lower levels of oxygen in its tissue by an increase of the respiratory frequency, as was observed in $M$. roosevelti. This is observed not only after intoxication with chemicals, but always when there is a change in the respiratory lamellae, caused by any environmental changes (FantaFeofiloff et al., 1986; Fanta et al., 1989; 1995).

The microridges are structures commonly found on the branchial surface of the fish (Eiras-Stofella et al., 2001). Their location and functions, however, generate discussions. Datta Munshi and Hughes (1986) studied the breathing surface of the gills of Anabas testudineus and found microridges in the epithelial cells of the respiratory lamella. Hossler et al. (1986) showed a branchial structure similar to the one found in Metynnis roosevelti, through ultrastructural studies. The microridges, called microfolds, are present in the arch and branchial filaments of Morone saxatilis, but they are absent in the respiratory lamellae that are covered by squamous cells with smooth surface. The authors remind that the presence of microridges in the epithelium of the respiratory lamellae has been related to the mucus anchor in order to protect this epithelium against microbial or solid agents in suspension. But they suggest that the absence of such structures in this epithelium can be good to reduce the thickness of the blood/water barrier, what facilitates the gaseous exchanges. 
Hughes (1979) proposes different functions for the microridges that were found on the surface of the respiratory lamellae of trout, Salmo gairdneri, such as the increase of breathing surface, the possibility of gaseous exchanges and the production of microturbulence that would facilitate the reception of $\mathrm{O}_{2}$. A possible function, however, would be the occupation of the space among the microridges by mucus, therefore promoting a flat surface for the flow of water on top of the epithelium of the gills.

The microridges in $M$. roosevelti are concentrically arrangement in the gill arches and branchial filaments. However, under the action of the sublethal concentration of $1 \mathrm{ppm} \mathrm{OP}$, a progressive alteration was observed in the shape of the microridges, that disappeared in some cells after $96 \mathrm{~h}$ of exposition.

Mallatt et al. (1985) showed similar results when they investigated the way of action of a specific poison in the branchial system of lamprey larvae. The authors describe both rare microridges with varied length and forms and alterations in the contact border among underlying cells, that became less evident, after treatment with sublethal doses. The alarming fact in this result is that the substance that was used by the authors was a poison that is specific against the tested organism. If these alterations on the surface of the gills reflect the way of toxic action of the poison, one can assume that $1 \mathrm{ppm}$ methyl parathion, even being a sublethal dose, was extremely toxic for $M$. roosevelti.

Sprage (1973) defines bioassay as a test in which the quality or intensity of a substance is determined by the reaction of an organism exposed to this substance. Some questions, such as "Is that substance toxic?" or still "How toxic is that substance?", can be answered by toxicity tests. However, the question "How do these substances exercise their toxic effects?" cannot be answered by these tests because they are only based on the mortality caused by these substances. Using some tools, such as the cellular biology, the fragility of the use of the single concentration in that $50 \%$ of the individuals died (CL 50) as a safe limit for the population, can be noticed. Although the OP methyl parathion has not caused death of any fish after $96 \mathrm{~h}$, it generated morphologic alterations in the respiratory system of these animals, that certainly have ecological consequences.

In the present study, the fish were exposed to controlled conditions in laboratory bioassay.
However, it is possible to extrapolate the results for natural environmental conditions. Firstly, because some morphologic alterations were registered after a short period of exposition (1h), what can be considered enough time to reach confined fish to some restrict places, for example, small lakes. In addition, the fish did not exhibit escape reaction when exposed to the sublethal concentration. Secondly, the used doses (1ppm and $7 \mathrm{ppm}$ ) are insignificant if compared to the doses recommended for crops. In order to reduce the plague in the culture of tomato, for example, $110 \mathrm{ml}$ is recommended for each 100 liters of water, or $1,100 \mathrm{ppm}$ of the organophosphorous compound! Of course, this volume will be quite diluted if it contaminates a waterbody. Even so, reflection on the difference among the concentrations needs to be addressed.

A third point refers to how to use the product and the final label on the packagings. The product can be applied by costal vehicles, bulldozers or airplanes. The manual of the product alerts that, when using airplanes, the wind should be calm or weaker than $8 \mathrm{~km} / \mathrm{h}$, in order to avoid the contamination of close atmosphere. It also warns the consumers not to wash the packagings or the tools either in rivers or other waterbodies. Most of our farmers are not preparared to understand these warnings, therefore ignoring the cares with their own health (Bull and Hathaway, 1986).

The generalized use of Brachydanio rerio in toxicity tests all over the world, but also in Brazil, is also debatable, once this species does not belong to the Brazilian ichthyofauna. This problem seems already solved in developed countries. In the manual of U.S. Environmental Protection Agency, we found out that some data regarding the effects of the methyl parathion on aquatic organisms were not used, because such studies were carried out with non-resident species in the USA (EPA, 1986). Sprage (1973) is more demanding when not recommending the use of Pimephales promelas in laboratories of a certain area of the USA, because this species is non-native of this area.

The great difference of sensitivity to methyl parathion, by Brachydanio rerio and Metynnis roosevelti, reinforces the need of toxicity tests with native species for the establishment of "safe concentrations". On the other hand our results show also that further studies on the action of pesticides should be developed, since, even in "safe doses", they can be harmful to vital organs. This, on the other hand, will impair the state of 
health of individuals or a whole population in a certain region, affecting potentially the whole ecosystem.

\section{ACKNOWLEDGEMENTS}

The authors are grateful to CAPES/Brazil for funds, supporting the Master Course in Morphology, Departament of Cellular Biology, Universidade Federal do Paraná, and a scholarship to Marcelo Rubens Machado during the course of his study.

\section{RESUMO}

As brânquias são estruturas vitais para peixes, pois são o principal local de trocas gasosas, assim como parcialmente responsáveis pela osmorregulação, pelo equilíbrio ácido-básico, pela excreção de compostos nitrogenados e pela gustação. Compostos químicos na água podem alterar a morfologia das células branquiais de peixes, que se constituem, dessa forma, em um útil modelo para estudos de impacto ambiental. Visando investigar os efeitos de um composto organofosforado, o metil paration, em brânquias de peixes, exemplares de Metynnis roosevelti foram expostos a doses letais (7ppm) e subletais (1ppm) de Mentox 600 CE. Observações em microscopia óptica e eletrônica de varredura evidenciaram enrugamento do epitélio branquial, seguido por descolamento e hiperplasia. Externamente, os filamentos branquiais apresentaram desaparecimento gradual das microssaliências. Os resultados mostram que, mesmo em doses subletais, o organofosforado poderá levar o animal a sofrer conseqüências secundárias decorrentes das alterações da superfície de trocas gasosas e iônicas.

\section{REFERENCES}

Abel, P. D. (1976), Toxic action of several lethal concentrations of an anionic detergent on the gills of the brown trout (Salmo trutta L.). J. Fish. Biol., 9, 441-446.

Arillo, A.; Margiocco, C. and Melodia, F. (1979), The gill sialic acid content as an index of environmental stress in rainbow trout, Salmo gairdneri Richardson. J. Fish. Biol., 15, 405-410.
Barberá, C. (1976), Pesticidas agrícolas. Ediciones Omega.

Bettex-Galland, M. and Hughes, G. M. (1973), Contractile filamentous material in the pillar cells of fish gills. J. Cell. Sci., 13, 359-370.

Bolis, L. and Rankin, J. C. (1980), Interactions between vascular actions of detergent and catecholamines in perfused gills of european eel, Anguilla anguilla L. and brown trout, Salmo trutta L. J. Fish. Biol., 16, 61-73.

Bull, D. and Hathaway, D. (1986), Pragas e venenos: agrotóxicos no Brasil e no terceiro mundo. Editora Vozes.

Culling, C. F., Allison, R. T. and Barr, W. T. (1985), Cellular pathology technique. London, Butterworth.

Datta-Munshi, J. S. and Hughes, G. M. (1986), Scanning electron microscopy of the respiratory organs of juvenile and adult climbing perch, Anabas testudineus. Japanase Journal of Ichthyology, 33, 39-45.

Davis, P. W. and Wedemeyer, G. A. (1971), $\mathrm{Na}^{+} \mathrm{K}^{+}-$ activated-ATPase inhibition in rainbow trout: a site for organochlorine pesticide toxicity? Comp. Biochem. Physiol., 40B, 823-827.

Daye, P. G. and Garside, E. T. (1980), Structural alterations in embryos and alevins of the Atlantic salmon, Salmo salar L., induced by continuous or short-term exposure to acidic levels of pH. Can. J. Zool., 58, 27-43.

Eiras-Stofella, D. R.; Charvet-Almeida, P.; Fanta, E. and Vianna, A. C. C. (2001), Surface ultrastructure of the gills of the mullets Mugil curema, M. liza and M. platanus (Mugilidae, Pisces). Journ. Morphol., 247, 122-133.

EPA (1986), Ambient water quality criteria for parathion. Washington, DC.

Epstein, F. H.; Silva, P. and Kormanik, G. (1980), Role of Na-K-ATPase in chloride cell function. Am. J. Physiol., 238, 246-2501.

Evans, D. H. (1987), The fish gill: site of action and model for toxic effects of environmental pollutants. Environmental Health Perspectives, 71, 47-58.

Evans, D. H. and Cameron, J. N. (1986), Gill ammonia transport. Journal of Experimental Zoology, 239, 17-23.

Evans, D. H.; Claiborne, J. B.; Farmer, L.; Mallery, C. and Krasny, E. J. (1982), Fish gill ionic transport: methods and models. Biol. Bull., 163, 108-130.

Fanta, E. (1995), Influence of the background color on the behavior of the fish Oreochromis niloticus (Cichlidae). Arq. Biol. Tecnol., 38, 1237-1251.

Fanta, E.; Lucchiari, P. H. and Bacila, M. (1989), The effect of environmental oxygen and carbon dioxide levels on the tissue oxygenation and the behaviour of Antarctic fish. Comp. Biochem. Physiol, 93A, 819-831. 
Fanta, E.; Luvizotto, M. F. and Meyer, A. P. (1995), Gill structure of the Antartic fishes Notothenia (Gobionotothen) gibberifrons and Trematomus newnesi (Nototheniidae) stressed by salinity changes and some behavioral consequences. Antartic Record (Nankyoku Shiryô), 39 : (1), 25-39.

Fanta-Feofiloff, E.; Eiras, D. R. de B.; Boscardim, A. T. and Lacerda-Krambeck, M. (1986) Effect of salinity on the behaviour and oxygen consumption of Mugil curema (Pisces, Mugilidae). Physiol. and Behav., 36, 1029-1034.

Flik, G. and Verbost, P. M. (1993), Calcium transport in fish gills and intestine. J. Exp. Biol., 184, 17-29.

Goldstein, L. (1982), Gill nitrogen excretion. In-Gills, Cambridge University Press. pp. 193-206.

Gonzales, R. J. and McDonald, D. G. (1992), The relationship between oxygen consuption and ion loss in a freshwater fish. J. Exp. Biol., 163, 317-332.

Goss, G. G.; Perry, S. F.; Wood, C. M. and Laurent, P. (1992), Mechanisms of ion and acid-base regulation at the gills of freshwater fish. Journal of Experimental Zoology, 263, 143-159.

Hossler, F. E. (1980), Gill arch of the mullet, Mugil cephalus. III. Rate of response to salinity change. Am. J. Physiol., 238, 160-164.

Hossler, F. E.; Harpole, J. H. and King, J. A. (1986), The gill arch of the striped bass, Morone saxatilis. I. Surface ultrastructure. J. Sci. Microsc. Cytol., 18 : (3), 519-528.

Hughes, G. M. (1966), Species variation in gas exchange. Proceedings of the Royal Society of Medicine, 59 : (6), 494-500.

Hughes, G. M. (1979), Scanning electron microscopy of the respiratory surfaces of trout gills. J. Zool., 188, 443-453.

Hughes, G. M. (1982), An introduction to the study of gills. In: Gills, ed. Cambridge University Press. pp. 1-24.

Kawall, H. G. (1993), Efeitos de águas ácidas em Gymnocorymbus ternetzy (Boulenger, 1895) (Pisces: Characidae). MSc Thesis, Universidade Federal do Paraná, Curitiba, Brasil.

Khan, R. A. and Kiceniuk, J. (1984), Histopathological effects of crude oil on Atlantic cod following chronic exposure. Can. J. Zool., 62, 2038-2043.

Laurent, P. and Perry, S. F. (1991), Environmental effects on fish gill morphology. Physiological Zoology, 64 : (1), 4-25.

Lin, H. and Randall, D. (1991), Evidence for the presence of an electrogenic proton pump on the trout gill epithelium. J. Exp. Biol., 161, 119-134

Lindesjöö, E and Thulin, J. (1994), Histopathology of skin and gills of fish in pulp mill effluents. Dis. Aquat. Org., 18, 81-93.
Lock, R. A. C. and van Overbeeke, A. P. (1981), Effects of mercuric chloride and methylmercuric chloride on mucus secretion in rainbow trout, Salmo gairdneri Richardson. Comp. Biochem. Physiol., 69 C, 67-73.

Luvizotto, M. F. (1994), Efeito de diferentes salinidades sobre as células de cloreto e as células secretoras do epitélio branquial do peixe antártico Nototheniops nudifons (Lonnberg, 1905). MSc Thesis, Universidade Federal do Paraná, Curitiba, Brasil.

Magor, B. G. (1988), Gill histopathology of juvenile Oncorhynchus kisutch exposed to suspended wood debris. Can. J. Zool., 66, 2164-2169.

Mallatt, J. (1985), Fish gill structural changes induced by toxicants and other irritants: a statistical review. Can. J. Fish. Aquat. Sci., 42, 630-648.

Mallatt, J.; Ridgway, R. L. and Paulsen, C. (1985), Ultrastructural effects of 3-trifluor-4-nitrophenol on gills of the larval lamprey Petromyzon marinus. Can. J. Zool., 63, 155-164.

Matthiessen, P. and Brafield, A. E. (1973), The effects of dissolved zinc on the gills of the stickleback Gasterosteus aculeatus L. J. Fish. Biol., 5, 607-613.

McDonald, D. G. (1983), The effects of $\mathrm{H}^{+}$upon the gills of freshwater fish. Can. J. Zool., 61, 691-703.

McDonald, D. G.; Cavdek, V. and Ellis, R. (1991), Gill design in freshwater fishes: interrelationships among gas exchange, ion regulation, and acid-base regulation. Physiological Zoology, 64 : (1), 103-123.

McKim, J. M. and Erickson, R. J. (1991), Environmental impacts on the physiological mechanisms controlling xenobiotic transfer across fish gills. Physiological Zoology, 64 : (1), 39-67.

Mitz, S. V. and Giesy, J. P. (1985), Sewage effluent biomonitoring. I. Survival, growth, and histopathological effects in channel catfish. Ecotoxicology and Environmental Safety, 10, 22-39.

Mueller, M. E.; Sanchez, D. A.; Bergman, H. L.; McDonald, D. G.; Rhem, R. G.; Wood, C. M. (1991), Nature and time course of acclimation to aluminum in juvenile brook trout (Salvelinus fontinalis). II. gill histology. Can. J. Fish. Aquat. Sci., 48, 2016-2027.

Nowak, B. (1992), Histological changes in gills induced by residues of endossulfan. Aquatic Toxicology, 23, 65-84.

Oliveira Ribeiro, C. A.; Turcati, N. M.; Carvalho, C. S.; Cardoso, R. and Fanta, E. (1994), Efeito tóxico do $\mathrm{HgCl}_{2}$ na estrutura dos arcos branquiais de Trichomycterus brasiliensis (Pisces, Siluroidei). Ann. II Simpósio sobre Meio Ambiente, Univ. Salgado de Oliveira, Niterói, Brasil.

Oronsaye, J. A. O. and Brafield, A. E. (1984), The effect of dissolved cadmium on the chloride cells of the gills of the stickleback, Gasterosteus aculeatus L. J. Fish. Biol., 25, 253-258. 
Randall, D. (1982), Blood flow through gills. In-Gills. Cambridge University Press. pp. 173-192.

Rankin, J. C.; Stagg, R. M. and Bolis, L. (1982), Effects of pollutants on gills. In-Gills. Cambridge University Press. pp. 207-220.

Rao, K. S. P. and Rao, K. V. R. (1981), Lipid derivatives in the tissues of the freshwater teleost, Saurotherodon mossambicus (alias Tilapia mossambica) (Peters) - effect of methyl parathion. Proc. Indian Natn. Sci. Acad., 47B : (1), 53-57.

Rios, F. S. and Fanta, E. (1998), Morphology of gill rackers and their ecological function in feeding of the Antarctic fish Notothenia neglecta Nybelin. Antarctic Record (Nankyoku Shiryô), 42, 131-150.

Rodrigues, E. L. and Fanta, E. (1998), Liver histopathology of the fish Brachydanio rerio after acute exposure to sublethal levels of the organophosphate Dimetoate 500. Revista Brasileira de Zoologia, 15 : (2), 441-450.

Romão, S.; Freire, C. A. and Fanta, E. (2001), Ionic regulation and $\mathrm{Na}, \mathrm{K}$-ATPase activity in gills and kidney of the aglomerular Antarctic fish Notothenia neglecta upon exposure to seawater dilution. Journ. Fish Biol., 55.

Sayer, M. D. J. and Davenport, J. (1987), The relative importance of the gills to ammonia and urea excretion in five seawater and one freshwater teleost species. J. Fish Biol., 31, 561-570.

Schimid, O. J. and Mann, H. (1961), Action of a detergent (dodecylbenzenesulphonate) on the gills of the trout. Nature, 192, 675.

Silva, H. C., Medina, H. G. S., Fanta, E. and Bacila, M. (1993), Sublethal effects of the organophosphate Folidol 600 (Methyl parathion) on Callichthys callichthys (Pisces, Teleostei). Comparative Biochemistry and Physiology, 105C : (2), 197-201.

Skidmore, J. F. (1970), Respiration and osmoregulation in rainbow trout with gills damaged by zinc sulphate. J. Exp. Biol., 52, 481-494.

Smart, G. (1976), The effect of ammonia exposure on gill structure of the rainbow trout (Salmo gairdneri). J. Fish. Biol., 8, 471-475.

Soderberg, R. W.; McGee, M. V. and Boyd, C. E. (1984), Histology of cultured channel catfish, Ictalurus punctatus (Rafinesque). J. Fish. Biol., 24, 683-690.
Sprage, J. P. (1973), The abc's of pollutant bioassay using fish. In: Biological methods for the assessment of water quality. Philadelphia, pp. 6-30.

Stoker, P. W.; Larsen, J. R; Booth, G. M. and Lee, M. L. (1985), Pathology of gill and liver tissues from two genera of fishes exposed to two coal-derived materials. J. Fish. Biol., 27, 31-46.

Verbost, P. M.; Schoenmakers, T. J. M.; Flik, G. and Wendelaar Bonga, S. E. (1994), Kinetics of ATP and $\mathrm{Na}^{+}$gradient driven $\mathrm{Ca}^{+2}$ transport in basolateral membranes from gills of freshwater and seawater adapted tilapia. J. Exp. Biol., 186, 95-108.

Wendelaar Bonga, S. E. and Lock, R. A. C. (1992), Toxicants and osmorregulation in fish. Netherlands Journal of Zoology, 42 : (2-3), 478-493.

Received: August 17, 2001; Revised: January 03, 2002; Accepted: September 27, 2002. 